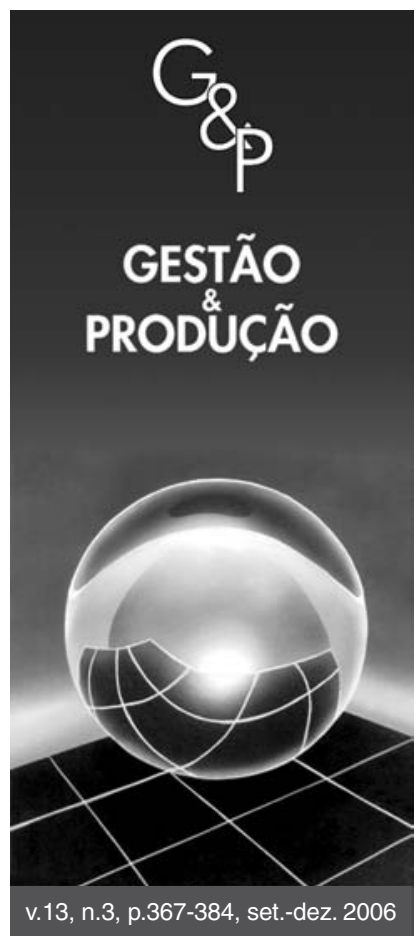

\title{
REMANUFACTURING APPROACHES CONTRIBUTING TO SUSTAINABLE ENGINEERING
}

\author{
Günther Seliger \\ Sebastian Kernbaum \\ Marco Zettl \\ Institute for Machine Tools and Factory Management, University Berlin, \\ Pascalstr. 8-9,10587 Berlin, Germany, \\ e-mail: seliger@mf.tu-berlin.de, sebastian.kernbaum@mf.tu-berlin.de, \\ marco.zettl@mf.tu-berlin.de
}

Abstract

Increasing use of resources by an increasing population with unequally distributed wealth make sustainability an urgent topic to pay attention to. A reference model for sustainability in engineering is presented referring to education and research, management, technology, processes and products as the relevant issues for a global change to sustainability. The European environmental laws for sustainable development are an attempt to cope with this challenge by legislative means. The provocative reality of practical implementation in dealing with electric and electronic products after their usage phases in Europe is illustrated. Laboratory developments in disassembly and testing demonstrate the feasibility of remanufacturing. In addition, approaches to increase the efficiency of remanufacturing by improving the product design are introduced.

Keywords: sustainability, engineering, remanufacturing, design for remanufacturing, modularity.

\section{Introduction}

Sustainability is directed to enhance human living standards by harmonizing ecological, economical and socio-political needs while considering the availability of natural resources and ecosystems for future generations. More than half of global value creation of today is achieved by less than one tenth of the global population. A sustainable political, economical and social stability can only be achieved if mankind is able to create jobs worldwide and not only in the first world, as well as living conditions of human dignity.

Human creative imagination, knowledge, experience, skills and initiative by entrepreneurial action coin our living conditions. Overcoming poverty requires a minimum of resources, abilities and qualifications provided for everyone in the world to take initiative for value adding activities. An equal level of wealth for everyone with hardly any differences in people's living conditions takes away incentives for useful engagement. The accumulated income earned by a population in a community from the poorest to the richest member is described by the Lorenz curve. The equity factor relates individual welfare to overall equity (Figure 1).

Empirical statistical data show significant differences in equity factors within different countries and regions all over the globe (Figure 2). In reaching sustainability within the present globalization process, the crucial rule of achieving a higher level of equity worldwide is considered to be essential. More equity is a key concept discussed in the European Union to find consensus between regions of different levels of wealth. It is based on strictly limiting environmental burdens and co-funding development (Kämpke et al., 2003). It is integrated into the idea of tenfold growth with tenfold eco-efficiency (Schmidt-Bleek, 1993). 


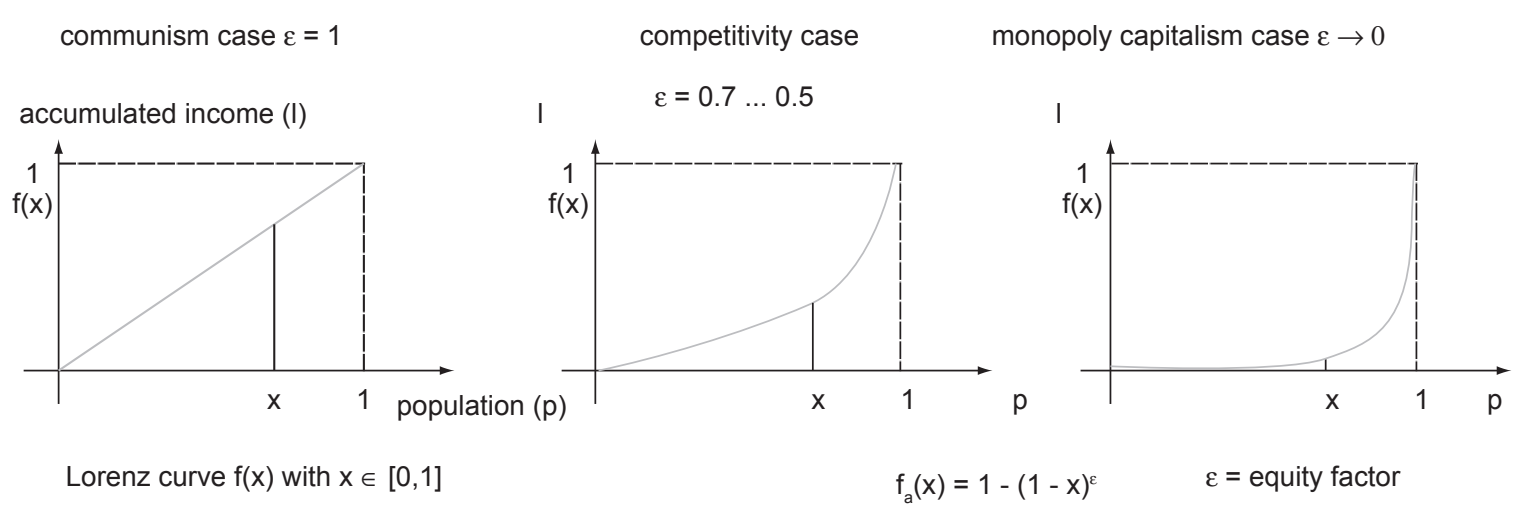

Figure 1. Lorenz curve and equity factor: quantitative instrument for describing the inequality in a society (Radermacher, 2002).

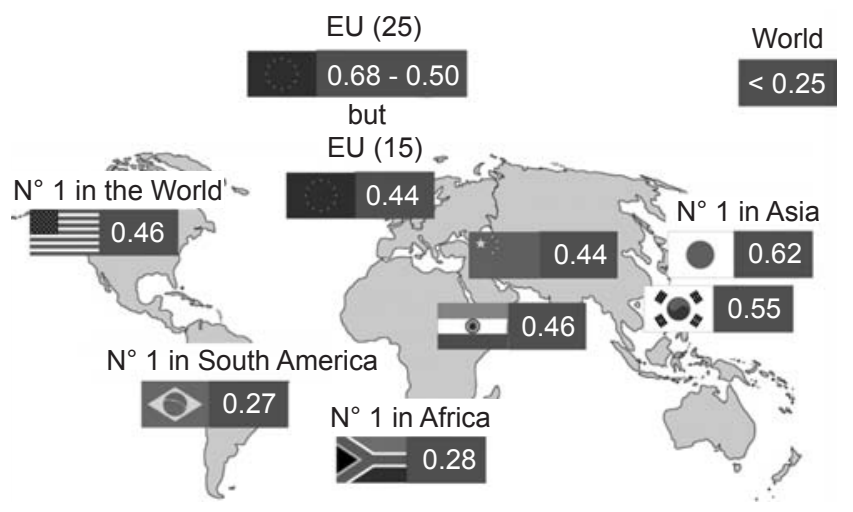

Figure 2. Different equity factors worldwide (Seliger, 2004).

\subsection{Sustainable engineering}

Sustainability is a task, which cannot be addressed only by individuals, single companies or single countries. Sustainability is rather an all-embracing, cross-sectional task including aspects of each engineering discipline, which have to be addressed on a global scale. From this point of view, the idea of sustainability has been interpreted with respect to engineering science within the Collaborative Research Center 281 on Disassembly Factories for the Recovery of Resources in Product and Material Cycles funded by the German National Science Foundation (DFG) at the Technical University of Berlin (TUB).

Sustainable Engineering can be defined as the application of scientific and technical knowledge to satisfy human needs in different societal frames without compromising the ability of future generations to meet their own needs. To achieve this goal, scientists and engineers cooperate in international and multidisciplinary groups and organizations. They use their imagination, judgement and take initiative to apply science, technologies and practical experience to shape competitive processes and products. Management guides the creation, application and evalu- ation of science, technology, processes, and products, as well as the dissemination of knowledge.

In Figure 3, the engineering perspectives in sustainability are illustrated, whereby human needs are represented as the MASLOW pyramid spanning all societies (Maslow, 1999). The different colored columns between human needs and the available resources describe the dissimilarity of conditions of the global society. Engineering challenges are the design of products and processes with improved usefulness and less environmental harm. Technology interpreted as science systematically exploited for useful purposes offers huge potentials to contribute. Technology enables processes to transform natural resources into products to meet human needs. The interaction between research and education imposes dynamics on how creative solutions are developed for relevant tasks.

\subsection{Resource productivity}

In order to achieve the ambitious goals of sustainability, a paradigm change in applying engineering has to be performed. Hereby, increasing the use of productivity of resources has to be investigated in order to satisfy human needs of the current and future generation without exceeding the ecological limits of the planet. Means of this approach are, e.g. expanding the life time of products, circulating resources, and distributed use of products. In Figure 4, the relation between resource productivity, standard of living, resource consumption and ecological limits are illustrated.

The question arises, which forces, e.g. legislation, entrepreneurial initiative or technological innovation are capable of reducing resource consumption or rather increasing resource productivity to avoid exceeding ecological limits. European legislation is analyzed regarding its effectiveness to cope with this challenge.

The following analysis is restricted to electric and electronic goods, because especially these products have a large impact on the environment. In fact, recent studies 


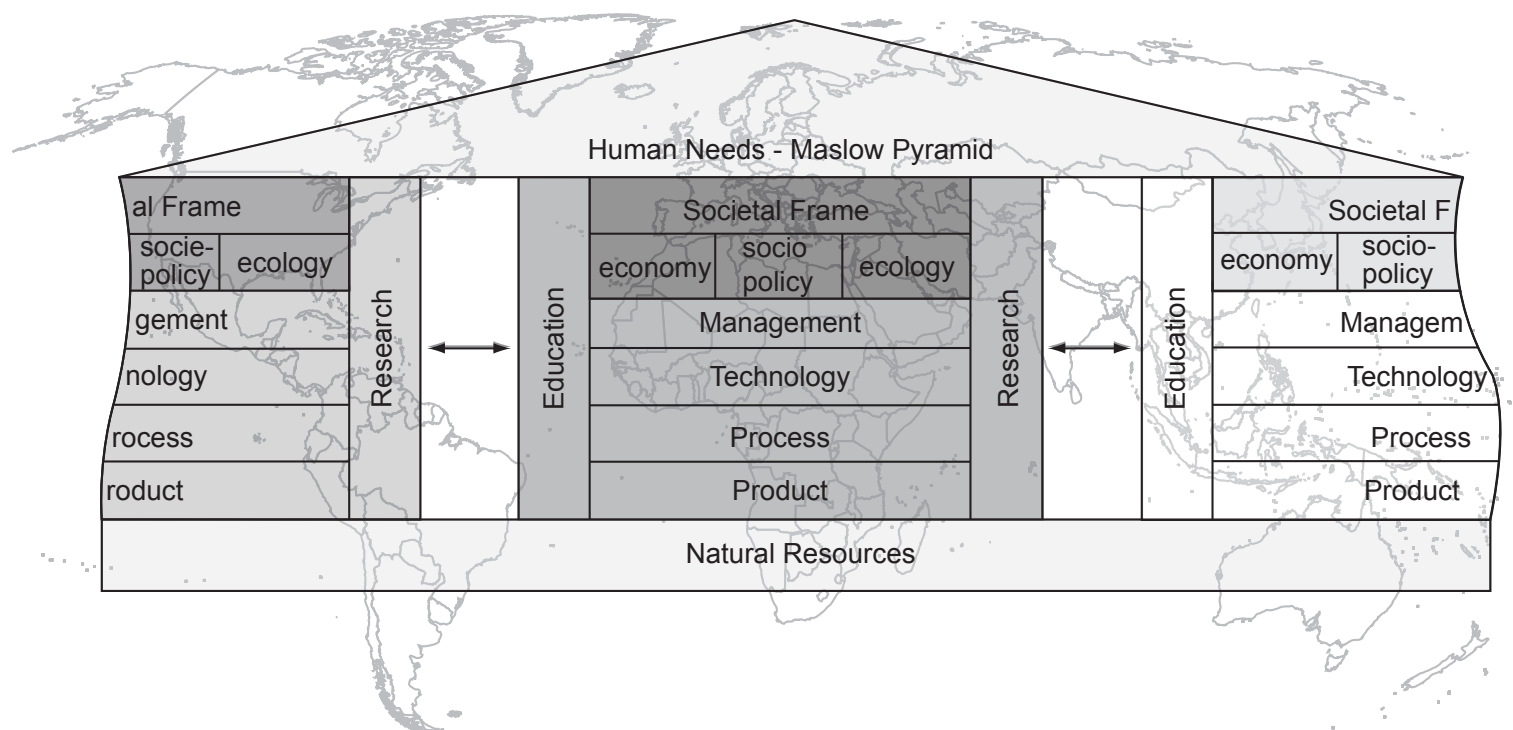

Figure 3. Engineering perspectives in Sustainability (Seliger, 2004).

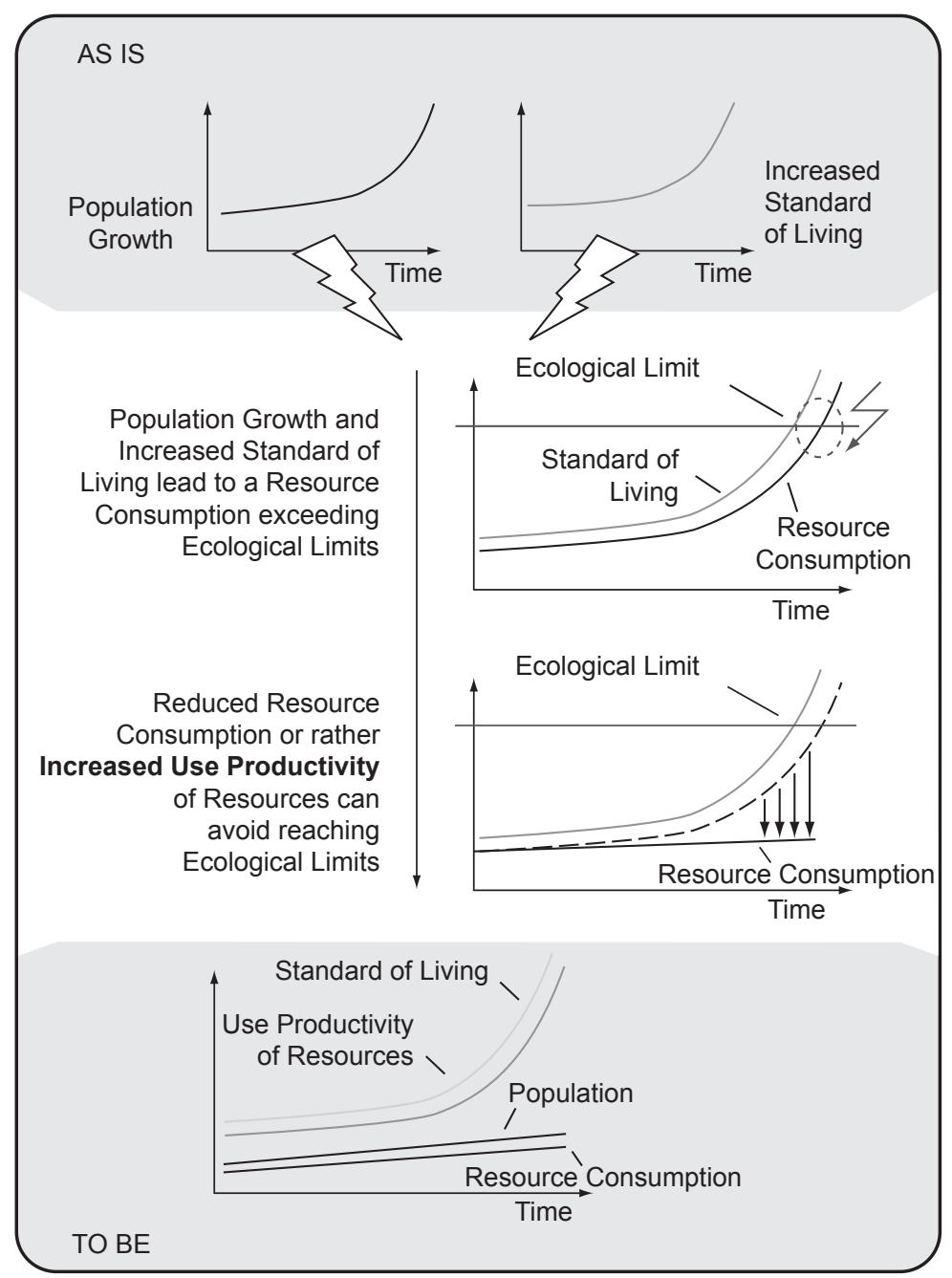

Figure 4. Impact of the use productivity of resources on global problems.

indicate that the major environmental impacts throughout the life cycle of electric and electronic equipment (EEE) occur in the material extraction and production stages
(Figure 5). For example, it has been shown that the production of a single microchip with a surface of $2.7 \mathrm{~cm}^{2}$ and a weight of $2 \mathrm{~g}$ consumes about 32 litres of water, 


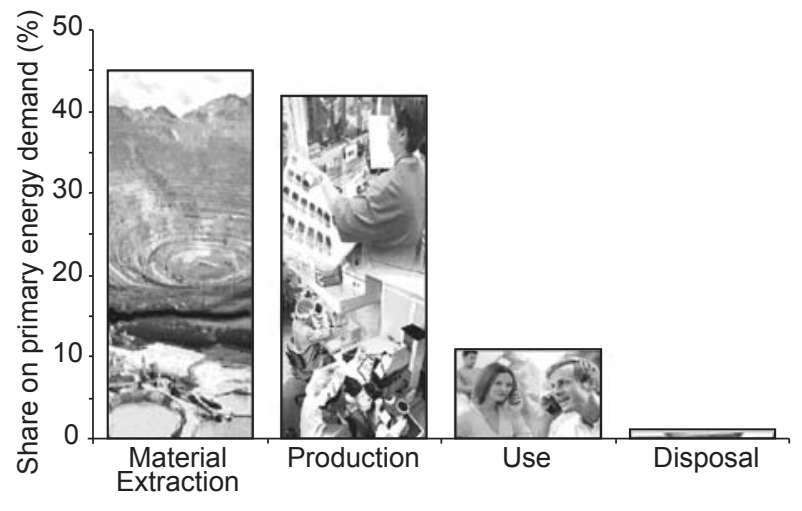

Figure 5. Share of the Primary Energy Demand of EEE throughout the Product Life Cycle (Basdere, B., 2004).

1.6 litres of fossil fuel, and 41 MJ of energy (Williams et al., 2002). Keeping in mind that many of the EEE, e.g. mobile tele-phones, are produced in large production volumes and are characterized by short time scales of technological and stylistic obsolescence the impact is multiplied respectively.

\subsection{European legislation - is it effective?}

On February 24, 1997 the European Council presented a resolution on a community strategy for waste management in the European Union (EU). The resolution insisted "... on the need for promoting waste recovery with a view to reducing the quantity of waste for disposal and saving natural resources, in particular by reuse, recycling, composting and recovering energy from waste". It was recognized that the "... choice of options in any particular case must have regard to environmental and economic effects but that until scientific and technological progress is made and life-cycle analyses are further developed, reuse and material recovery should be considered preferable where and in so far as they are the best environmental options." (The European..., 2002).

Based on this resolution, the European Parliament published the directive on waste electrical and electronic equipment (The European..., 2002) on January $27^{\text {th }}, 2003$ (WEEE) to specify and harmonize EEE shall be collected and treated at their end-of-life. The concept of producer responsibility forms the quintessence of the directive. The producer is responsible for financing the collection from collection facilities, as well as the treatment of recovery and disposal of WEEE. He should be allowed to choose to fulfill this obligation either individually or by joining a collective initiative. Furthermore, he shall provide a financial guarantee to prevent costs for the management of WEEE from orphan products.

EU member states were obliged to bring into force the laws, regulations and administrative provisions necessary to comply with the directive on WEEE. A comparison of the transposition of the directive in EC member states is well described in a frequently updated report published by Perchards (2005). In Germany, for instance, the Electrical and Electronic Equipment Act (ElektroG, German Bundesrat..., 2005) was adopted by the German Bundesrat and brought into force on March 23, 2005, obliging producers to start collecting and treating commercialized EEE beginning on March 24, 2006.

To understand the effectiveness of the directive one has to understand the meaning of the term 'waste'. In Germany, waste is defined in the German Closed Substance Cycle and Waste Management Act (KrW-/AbfG) from 1994 (German Bundesrat..., 1994). According to 33 Abs. $4 \mathrm{KrW}-/ \mathrm{AbfG}$ waste comprises all movable property in the categories specified in the law which the holder discards, or intends or is required to discard. The holder must discard movable property when such property is no longer used in keeping with its original purpose, and when, due to its specific state, it could endanger, either in the present or the future, the public interest, especially the environment.

In the context of the directive on WEEE, the specific state of the property addresses the integrity and functional capability of EEE. If declared functional neither $\mathrm{KrW}-/ \mathrm{AbfG}$ nor ElektroG need to be applied enabling for the equipment's free movement within and to destinations outside of the country. On the one hand, this can enable companies to re-market valuable equipment, e.g. IT equipment, into markets with high demand, e.g. in Eastern Europe or Africa. On the other hand, it leaves a door open for companies to bypass legislation.

In Germany today, the temptation of abusive interpretation of legislation is growing for producers and recyclers as well. Even when collected as waste, a product can be declared functional and then be treated as a normal commercial asset thereafter. Public authorities do not have sufficient personnel at their disposal to inspect all crossborder and oversea shipments of WEEE (ZDF..., 2006). It is at least questionable whether waste can be monitored and accounted for if producers implement individual collection and treatment schemes in cooperation with recyclers without proper inspections. False declaration of nonfunctional equipment can help to reduce treatment and disposal cost and thus bypass producers' responsibilities.

To avoid the environmentally harmful export of WEEE, stricter inspections are required but not sufficient. Recyclers and re-marketing companies must be enabled to benefit from the opportunities in remarketing of functional equipment and components without the need of exporting waste.

In Figure 6, the complexity regarding market actors and relationships that need to be dealt within European legislation on electronic waste is depicted. Figure 7 shows the 


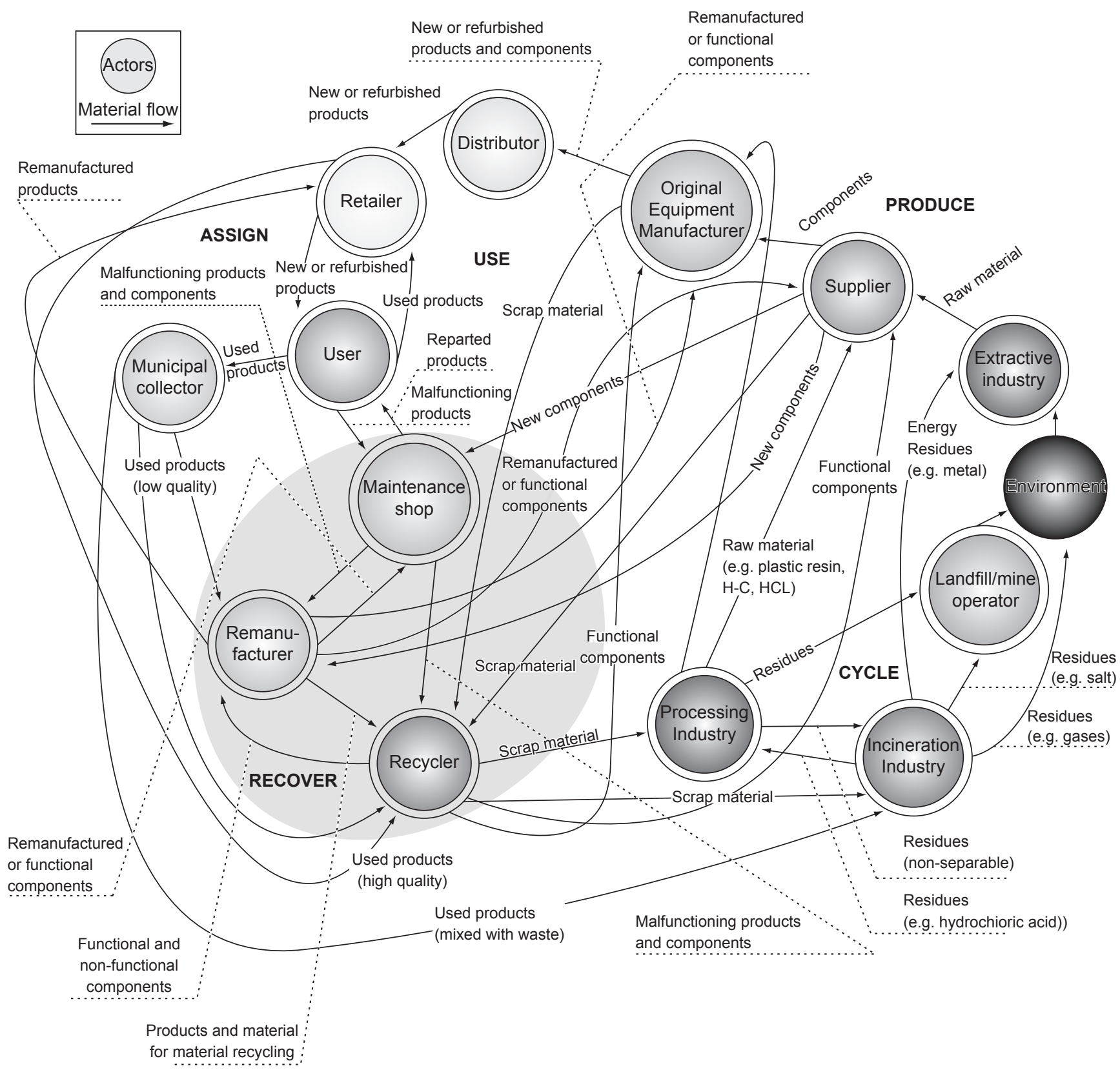

Figure 6. Complexity of closed loop economy (Franke et al., 2004).

provocative reality of exporting harmful non-functional electronic waste in containers via the Hamburg harbour. Officials neither have sufficient staff at their disposal, or the qualifications to test equipment in order to avoid illegal exports.

\subsection{Remanufacturing vs. Recycling}

To investigate the relative environmental emissions associated with recycling vs. remanufacturing, a Life Cycle Assessment (LCA) was conducted exemplarily for a mobile tele-phone. The results of the investigation showed as expected that mobile tele-phone production accounts for almost all of the non-energy related emissions in the life cycle. It was also found that the integrated circuits, display modules and main printed circuit boards accounted for nearly three-quarters of the energy consumed in the production phase. Not including integrated circuits manufacturing, the production stage itself consumed approximately $250 \mathrm{MJ}$ of energy, which was over two times the estimated amount of energy consumed by the normal use of the mobile tele-phone over two years (Guenther et al., 2003).

In Figure 8 the production, use and EoL energy consumption of two identical mobile tele-phones in the following three scenarios are illustrated: 1) both phones are manufactured and disposed at landfills without recycling 
or remanufacturing, 2) both phones are manufactured and completely recycled (even though $100 \%$ recycling is neither economically nor technically feasible), and 3) one phone is manufactured as-new, and the other identical phone is restored as-new from a discarded phone of the same model. The remanufacturing pathway has by far the least energy consumption. This is because the remanufacturing pathway, unlike recycling, avoids repeating

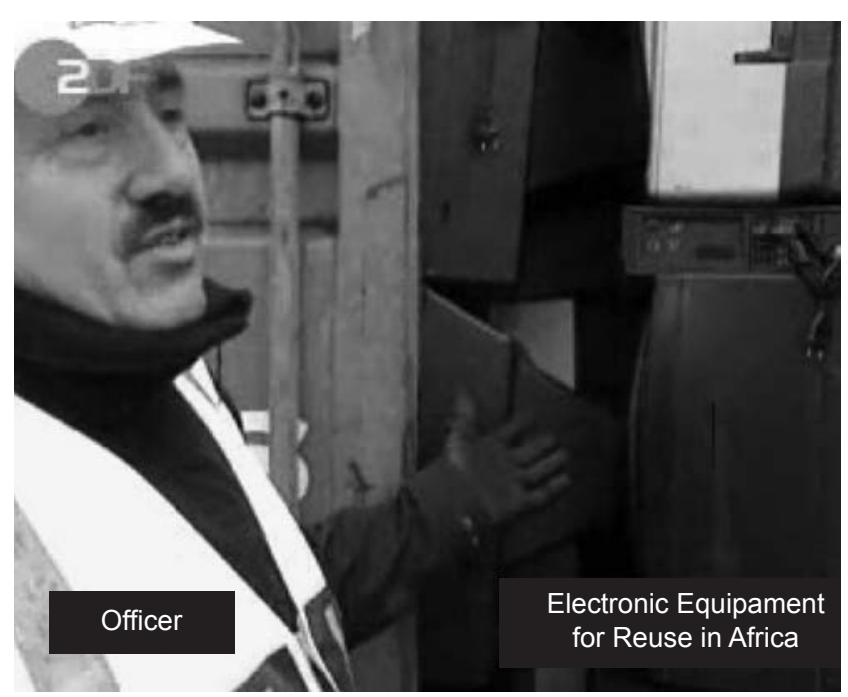

Figure 7. Hamburg Harbour (ZDF..., 2006).
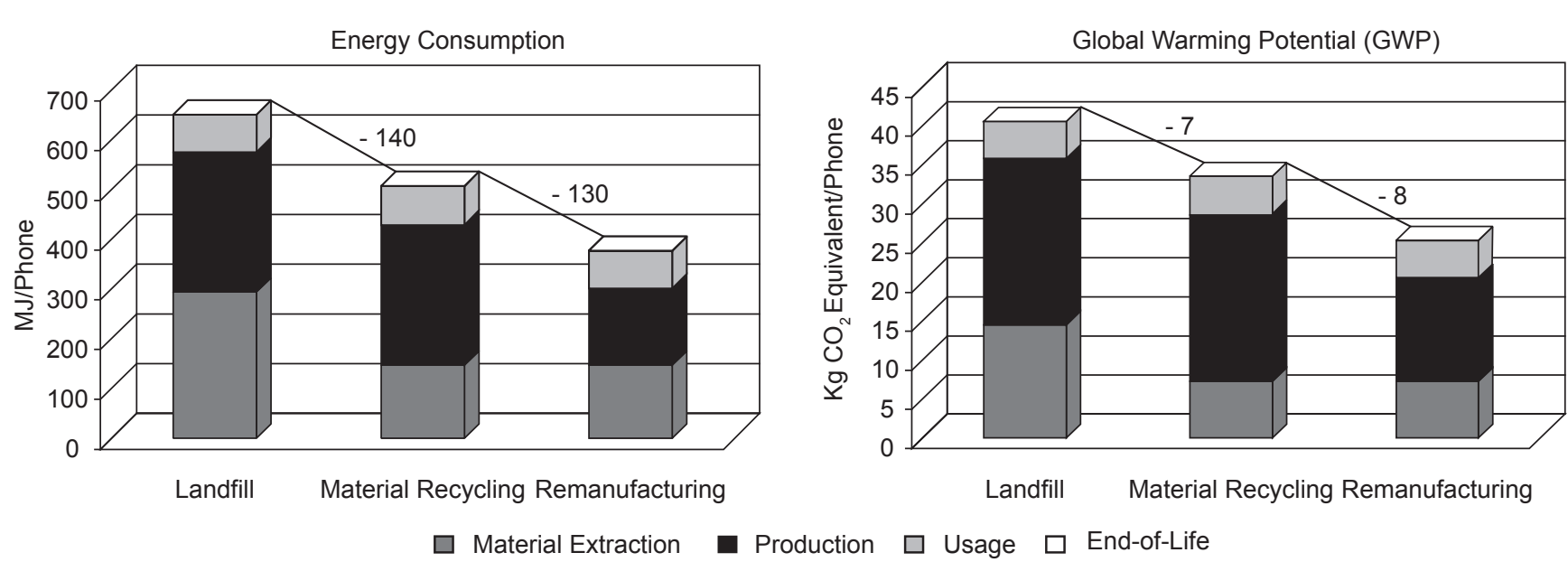

\section{Efficient remanufacturing processes}

Remanufacturing is already a profitable business field. In fact, companies in Europe and North America are making significant profits by selling remanufactured products and components, e.g. mobile tele-phones and automobile components, mainly in markets of emerging countries (Skerlos et al., 2004). However the potential of remanufacturing is not fully exploited yet. Complex

Production

manufacturing steps with characteristically high energy sumption and environmental emissions. The results manufacturing a mobile tele-phone represents approximately 10 days of energy consumption for the average potential for an average tree (Guenther et al., 2003).

Enabling technologies for sufficient remanufacturing are efficient remanufacturing processes and advanced product design using modularization techniques. Both processes, disassembly and testing are described in the example of LCD (Liquid Crystal Display) monitors. The improvement of the product design to increase the efficiency of remanufacturing is discussed in the example of a mobile tele-phone. remanufacturing is not fully exploited yet. Complex 
and manual processes, various product models, missing product information, high spare-part costs, quality problems as well as technological and stylistic obsolescence are making remanufacturing of many products unprofitable. An analysis of cost structures in the remanufacturing industry quickly revealed the major cost drivers: acquisition of cosmetic parts, manual sorting, disassembly and reassembly, as well as manual testing of functionality (Seliger et al., 2003).

\subsection{LCD monitor keyfacts}

The remarketing of used flat screen desktop monitors is evolving into a profitable market segment. Demand for used or non-functional monitors is growing especially in Eastern European countries and cannot be covered by End-of-Life (EoL) products, yet. Non-functional phaseout models are often sold to repair-shops in Eastern European countries, which is often associated with improper EoL treatment of non-reusable components. To avoid negative environmental impacts caused by today's practice in demand markets with slack environmental regulations, clean remanufacturing activities must be initiated at the returned product's origin.

The demand for flat screen monitors today is growing more. Used monitors are hardly available due to the low market penetration. In 2005 alone, about 137 Mio. desktop CRT (Cathod Ray Tube) and LCD monitors are expected to be sold (Figure 9). With 97 Mio. sold LCD monitors, their market share will reach about $71 \%$ (Alexander, 2004).

To estimate the return volume of used monitors that are to be disposed in 2005, one can assume the average monitor's usage time being approximately 4 years, i.e., considering the sales volume of 2001. In that year, about 100 Mio. desktop monitors were sold and the AMLCD monitor's market share was only $16 \%$, i.e., 16 Mio. units. According to a US National Safety Council (1999) report approximately $45 \%$ of computers and peripherals are be-

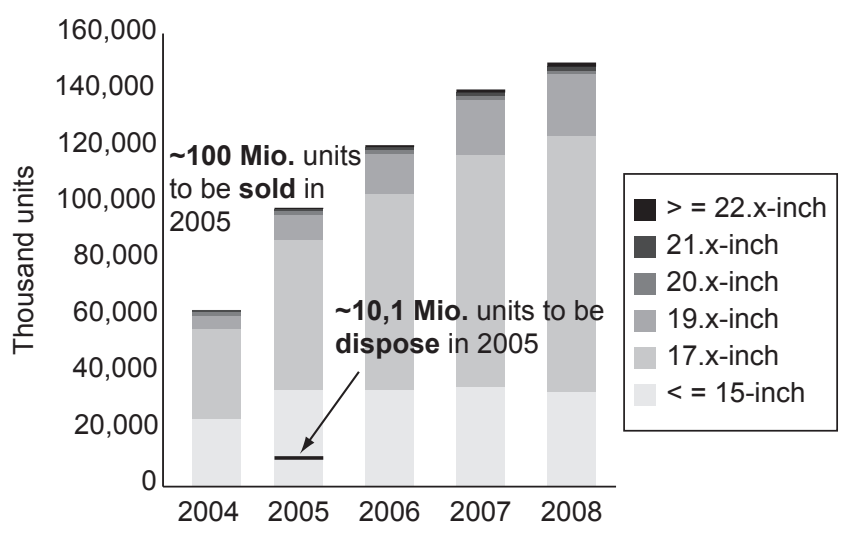

Figure 9. Worldwide AMLCD desktop monitor sales, own calculation and Alexander (2004). ing used for a second time, i.e. 55\%, or 8.8 Mio AMLCD monitors are disposed. In addition to this, one needs to consider those monitors that were used more than once, i.e. those that will return in 2005 , but were sold before 2001. According to NSC (1999) the average period for second usage is 2.5 years, i.e., $45 \%$ of monitors sold between mid 1998 and mid 1999 are used until 2005. With 1.3 Mio. AMLCD monitors sold in 1998 and 4.5 Mio. in 1999 [18] one can estimate the number of units to be disposed in 2005 form this period with 1.3 Mio. [ $\left(0.5^{*} 1.3+\right.$ $\left.0.5^{*} 4.5\right)^{*} 0.45$ ], resulting in a total of 10.1 Mio. AMLCD desktop monitors to be disposed worldwide in 2005.

Prices for used and non-functional 15"-18" monitors with control failures from private users - determined via the online market place eBay ${ }^{\mathrm{TM}}$ - usually range from $€$ 40 to approximately $€ 110$, as long as the LCD panel glass is not broken. Defective monitors from leasing returns collected by larger IT-remarketing companies from institutional users are frequently exported to Eastern Europe, where high demand meets cheap labor. An adequate EoL treatment of these monitors is at least very questionable.

From an ecological point of view, the shift from CRT to AMLCD technology can be considered a step towards sustainable development in the information and telecommunication sector, if monitors are treated properly at their EoL. A Life Cycle Assessment of desktop computer displays conducted by the University of Tennessee in 2001 compares the environmental and health impacts of AMLCD and CRT technologies (University of Tennessee, 2001). As an example, AMLCD manufacturing is water and energy intensive. The manufacturing life stage, i.e., mainly the glass manufacturing process, accounts for over $75 \%$ of the renewable resource use. Due to the 60\%-70\% lower weight as compared to CRT displays, the natural resource consumption of AMLCD is significantly lower. Energy consumption of AMLDC during use is also 60\%-70\% lower than for CRT displays.

\subsection{Recycling keyfacts}

In Germany today, only a few hundred tons of LCDs from flat screen monitors, including LCDs from television sets return for recycling. By 2012, the quantity of returned LCDs from these applications is expected to reach approximately 4,000 tons.

In Article 7 (2) of the European Directive on Waste Electric and Electronic Equipment (WEEE), the reuse and recycling targets for LCDs (group 3) are defined with $65 \%$ of the product's weight (The European, 2002). Annex II of the WEEE obliges disassembly of all LCDs with a surface greater than 100 square centimeters and all those back-lighted with gas discharge lamps, prior to material recycling. Figure 10 depicts the elements of a LCD module. 
The most relevant recycling facts for flat screen monitors are summarized below. Data obtained by a literature review is complemented by the analysis of a 4 year old 15 " flat screen monitor of a popular brand.

\subsubsection{Liquid crystal display (LCD)}

The LCD without printed circuit boards consists of approximately $87.2 \%$ glass, $12.7 \%$ foil and $0.1 \%$ liquid crystals (Martin et al., 2004). According to a statement by the German Federal Environmental Agency concerning the ecotoxicology of liquid crystals in liquid crystal displays, LCDs do not require special disposal, due to the content of liquid crystals (Ecotoxicology..., 2000)

Available and economically profitable recycling processes use LCD's glass as surrogates, e.g., instead of quarry sand in steel smelting processes, and plastics, i.e. foils, as an energy source for the smelting process (Martin et al., 2004). Recycling technologies for the recovery of the glass fraction for reuse in LCD manufacturing are still in an experimental state (Behrendt and Erdmann, 2003)

\subsubsection{Cold cathode fluorescence lamps (CCFLs)}

CCFL contain small quantities of mercury and require special treatment. CCFLs must be disassembled from the LCD module. Following the prognosis of the IZT (Behrendt and Erdmann, 2003) between $290 \mathrm{~kg}$ and $480 \mathrm{~kg}$ mercury will have to be disposed for all 80 Mio. flat screen monitors that will be in use by the year 2010 .

\subsubsection{Printed circuit boards (PCBs)}

Due to the mandatory disassembly and separate treatment of LCDs, printed circuit boards need to be separated from the LCD's glass and foil compound, usually by means of destructive disassembly.

\subsubsection{Plastics}

For the flat screen monitors analyzed, halogen free, i.e., bromide and chloride free plastics, e.g. PC + ABS -FR(40) or PC - FR(4), and acrylic glass were found. If separated properly, these plastics can be recycled for re-

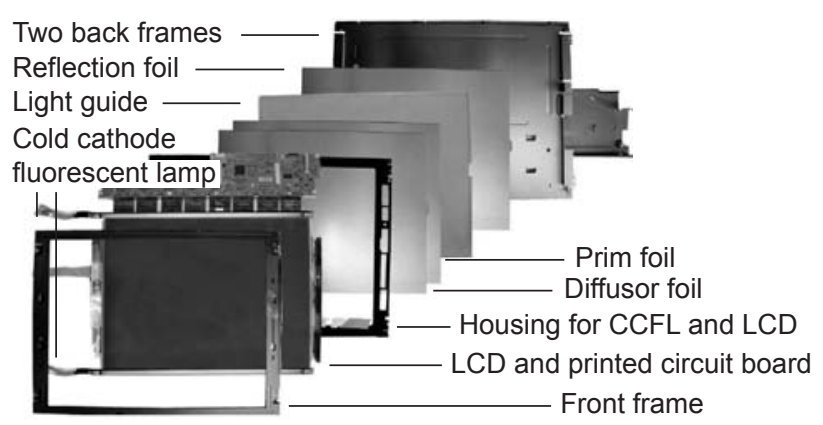

Figure 10. Components of a LCD module. use in similar applications.

Figure 11 depicts the relative distribution of material fractions for an analyzed 15" LCD module (1790 grams) and the flat screen monitor without stand (4,070 grams) including the LCD module, as depicted in Figure 11. The achievement of material recycling targets of $65 \%$ or higher can be looked upon as being realistic, if material fractions are separated before recycling. With $78 \%$ of the monitor's weight being perfectly separable ferrous metal, and plastic components, targets can be achieved even neglecting the glass and copper fractions from LCDs, respectively $\mathrm{PCBs}$ and wiring.

Extending the usage phase of flat screen monitors beyond today's average of four years is ecologically reasonable, due to the highly energy intensive production of LCDs and PCBs. Whether non-functional monitors can be prepared for another usage cycle economically depends on the costs for adequate take back, identification, testing, disassembly, spare part procurement and re-distribution. By means of a disassembly analysis, components suitable for reuse and the necessary disassembly effort are identified.

\subsection{Remanufacturing challenges}

With a predicted $90 \%$ penetration of the monitor market with flat screen technology by 2010, product returns will be sufficient to develop remanufacturing activities on a large scale. The main challenge, as in most remanu-

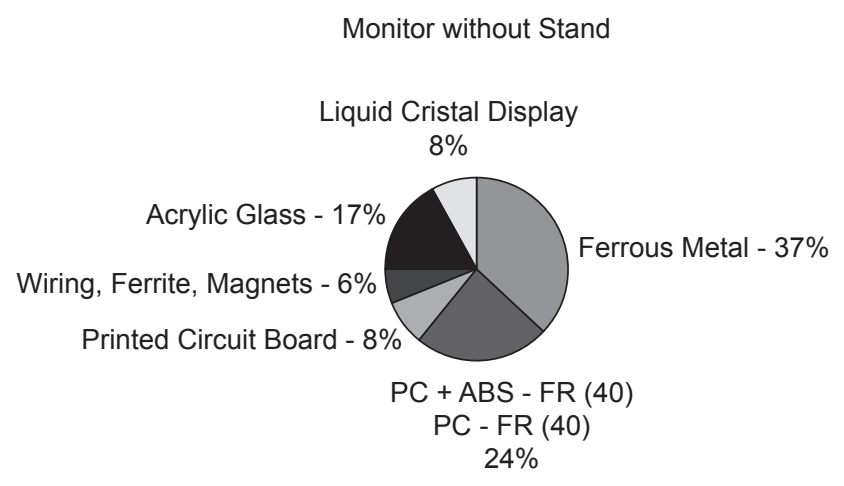

LCD Module

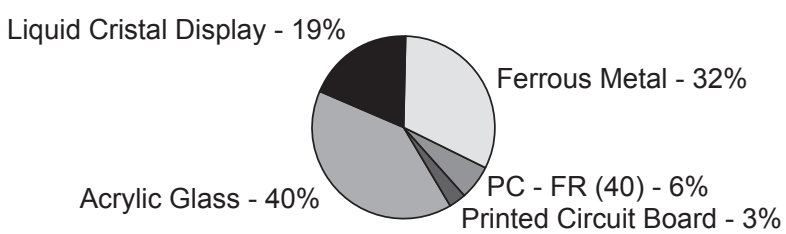

Figure 11. Relative distribution of material fractions. 
facturing activities, is the handling of uncertainty regarding time, quality, quantity and place of product returns that affects collection, testing, disassembly, reassembly and the warehousing of spare parts likewise.

\subsubsection{Collection}

Today, IT equipment returns from leasing contracts are frequently collected by IT remarketing companies. Due to the low market penetration of flat screen monitors, collection from private households is still uncommon. Future collection using today's municipal collection hubs is unlikely to guarantee an undamaged take back of flat screen monitors. To obtain access to product returns from private households, new take back models, e.g. charity recycling (Seliger et al., 2003), are required. Due to the dimension and weight of monitors, as compared to mobile phones, collection using the postal service is rather unlikely due to the high costs involved.

\subsubsection{Disassembly}

A disassembly analysis was conducted for 17 different flat screen monitors for module level (Figure 12).

Non-destructive disassembly of beyond warranty and non-functional, e.g. broken LCD modules are usually economically unfeasible and the LCD module is the monitor's primary value. Advanced repair processes, e.g. disassembly of tape adhesive bonding (TAB) for the recovery of driver tabs or the replacement of polarizers are predominantly applied during warranty or for highly integrated LCD modules, e.g., notebooks or industrial control panels. Being mandatory by law (The European..., 2002), the disassembly of LCDs from LCD modules is usually carried out destructively. All relevant components, i.e., frame, housing, LCD, foils, CCFLs, light guide and PCBs can be separated within approximately one minute.

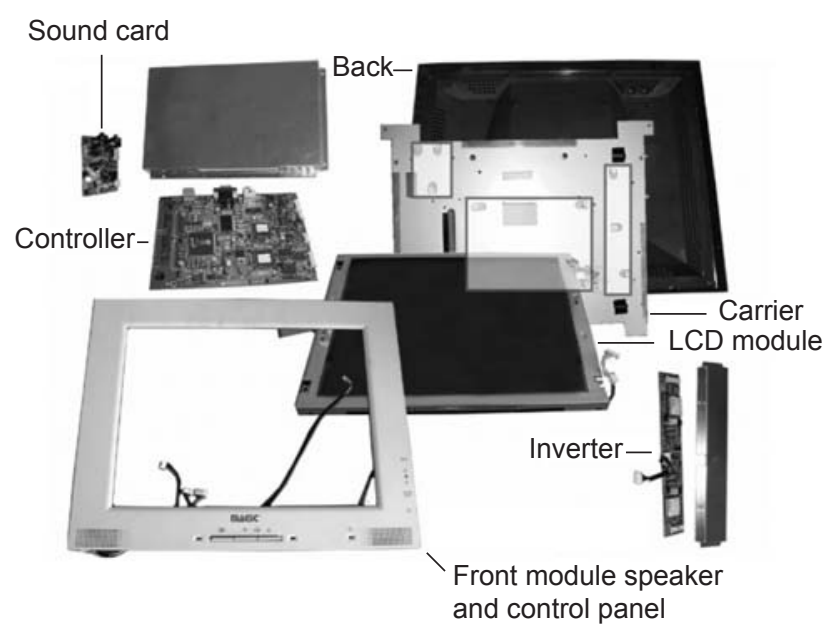

Figure 12. Flat screen monitor modules without stand.
Non-destructive disassembly of the monitor to module level is the prerequisite to enable the majority of remanufacturing processes to be carried out. The most common repair option for the LCD module is the replacement of CCFLs. Therefore, from now on, CCFLs are defined as a module of the flat screen monitor. Other common repair options for the LCD monitor include the replacement of faulty electronic components, as well as mechanical components such as plugs.

For a systematic evaluation of the monitor's relevant disassembly properties, the analysis was documented by means of a morphological box. To obtain comparable results regarding the disassembly effort required, a Method Time Measurement (MTM) analysis was conducted for all 17 monitor models. The disassembly times depending on monitor design range from 3.6 to 8.7 minutes and the quantity of screws used from 33 to 108 units. Disassembly properties and MTM results were summarized in Franke et al., 2005; 2006.

Particularly important for cost efficient disassembly is the provision of a suitable disassembly plan under consideration of the acquired test results for each product. A certain order of disassembly steps is usually predefined by the product design. Automation of selected disassembly, i.e. mainly unscrewing processes, can be an option once higher quantities of used flat screen monitors are available.

Based on the disassembly analysis of 17 monitor models, basic restraints regarding the automation of disassembly operations were identified as follows:

- very strong snap fits in housings parts due to the strong release torques required,

- stands mounted to the monitor's inside,

- integrated video or power supply cables requiring manual disassembly of the back housing, and

- electronic components mounted on the top and the bottom of the carrier, needing additional handling of the carrier.

The monitors selected for hybrid disassembly offer weak housing snap fits, externally mounted monitor stands, externally removable cables and electronic components mounted to one side of the carrier.

A prototypical hybrid disassembly system with one automated and one manual workplace connected by three square conveyor blocks was carried out. A 4-axis Selective Compliant Articulated/Assembly Robot Arm (Scara) was applied for unscrewing and handling operations. A manual workplace, originally used for manual testing of mobile phones, was adapted for manual disassembly and reassembly operations and integrated in the system. The system can be extended to one more automated and five more manual workplaces to accommodate further disassembly, as well as testing and reassembly operations. 
At the manual workplace, the monitor is positioned on the work piece carrier. Large monitor stands are disassembled manually and small ones remain mounted to the back housing as long as they do not interfere with the accessibility of joining elements. The monitor is transferred to the automated disassembly workplace (Figure 13). A suction gripper is used to pick up the monitor and position it on the pneumatic clamping device. External screws, the monitor back housing and internal components are removed. Metal covers, printed wiring boards and cable connectors are removed respectively disconnected using a two-finger gripper. In case a process fails, the monitor is forwarded to the manual workplace.

The material flow in the above described disassembly system is physically carried out by means of a conveyor

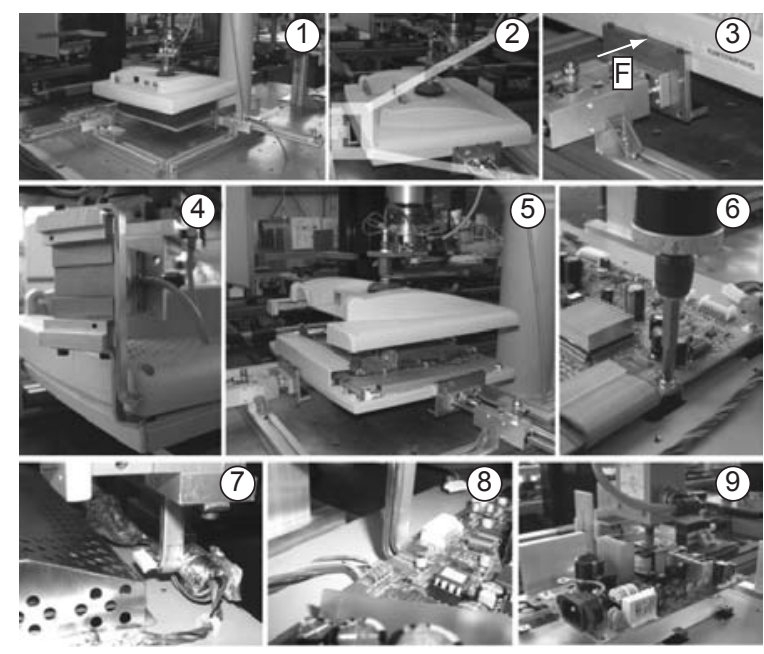

(1) Positioning of the monitor

$(2,3)$ Clamping the monitor

$(4,5)$ Opening the housing

(6) Unscrewing of circuit board

(7) Decoupling of cable connector

$(8,9)$ Handling of circuit boards

Figure 13. Automated disassembly process. system and all drives, sensors and actuators are operated using a modern control system.

An efficient use of this equipment requires a computer aided planning approach, which can be supported by many simulation tools (Franke and Kernbaum, 2005).

In the first step, a 3-D model of the system was modeled using eM-Workplace. Conveyors, sensors, actuators and pallets are represented graphically without logic. In the second step, the model is extended by means of control functions, e.g. the functionality of an optical sensor used to activate a mechanical stopper as a result of the detection of a moving pallet. In the third step eM-PLC is applied to generate operation sequences to be used with programmable logic controllers (PLC).

These control sequences can be represented in a user friendly manner and transformed into PLC commands using STEP 7. Based on the real PLC, a virtual PLC can be configured and tested using these commands. Using the virtual PLC, the system can be tested for logic faults in a short time and without the need of real material movement. Therefore, the virtual start-up as illustrated in Figure 14 can help reduce real start-up time and help avoid start-up problems.

\subsubsection{Testing}

Testing is to determine, whether a testing object is fulfilling one or more agreed, required or expected terms, especially whether given error margins and tolerances were met. Electric or electronic devices are basically tested when assembled - alternatively, testing can be applied to components after disassembly.

Testing methods for assembled LCD monitors were systematized in six categories, where order is derived from the expected time and cost effort for testing. The testing procedure starts with the process that has the lowest effort and is shown in Figure 15. If an error occurs when the testing procedure is being carried out in one of the testing processes, the next testing process cannot

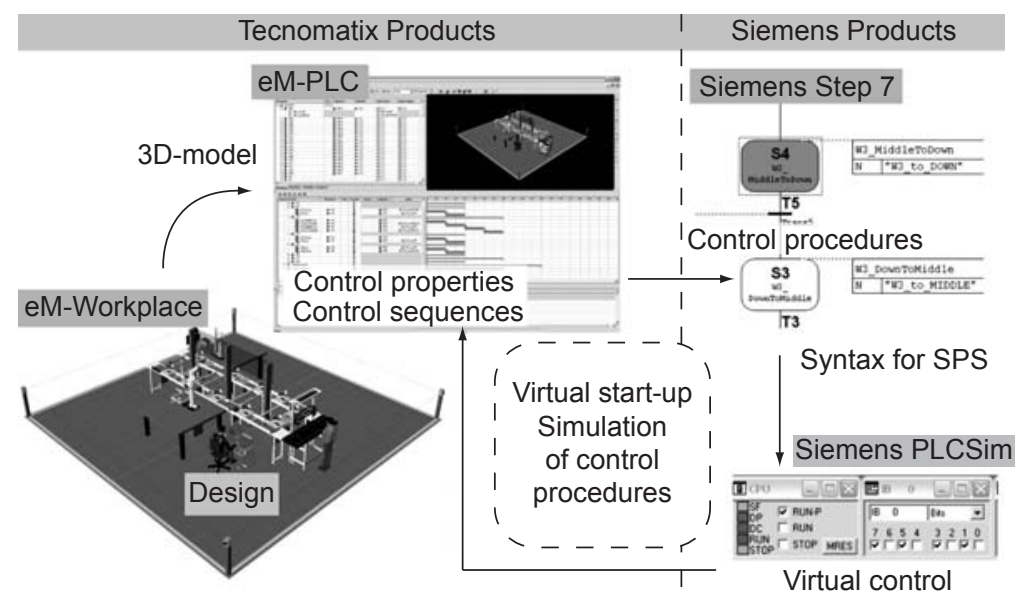

Figure 14. Steps to virtual start-up. 


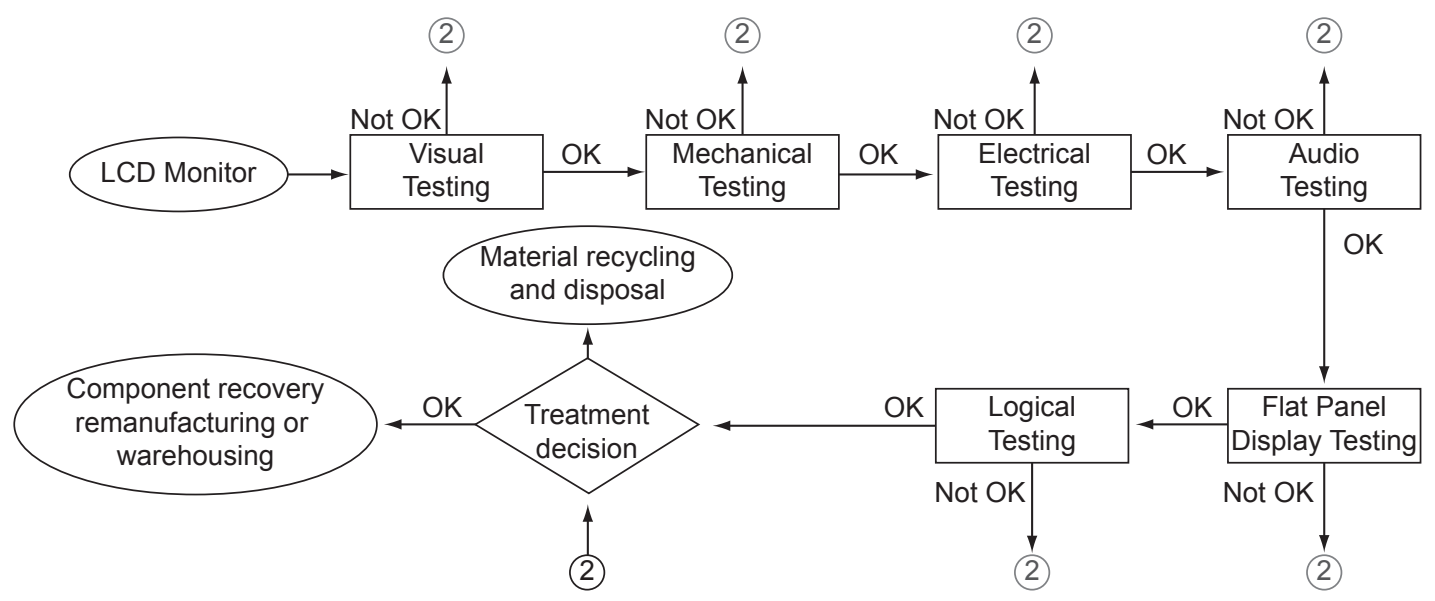

Figure 15. Testing process chart.

be initiated as well as options of destructive and non-destructive disassembly results.

Detailed inspection instructions and inspection records, as well as flow charts for visualization were developed for the considered testing methods, which will be explained exemplarily below.

\subsubsection{Visual testing}

The visual testing of LCD monitors comprises inspection of the front and back housing modules, operating controls, all electronic connectors (graphic, power supply, sound I/O, possible USB connections), possible attached wires for the connection to PC's, monitor stands and LCD modules. Observable errors are breakages, scratches or the absence of one or more element. For the better estimation of remanufacturing options, quality classes can be defined as given exemplarily in Table 1.

Cleaning before inspection and determination of surface quality can help to improve the rating process. No special equipment is necessary for visual testing except some cleaning tissues. Devices that pass the visual test are assigned to the mechanical test.

\subsubsection{Mechanical testing}

During the mechanical testing process, the connections of the electrical components controller (graphic, power and/or USB connectors), converter and sound card are tested with respect to mechanical damage. In the course of mechanical testing, power and data connections are established for subsequent tests.

\subsubsection{Electrical testing}

Backlight functionality and basic LCD-Module functionality are determined by means of a test signal in the course of electrical testing. Exemplary tests have shown that the test signal can be detected even without backlight functionality.
Table 1. Quality classes for components.

\begin{tabular}{llll}
\hline \multirow{2}{*}{ Component } & \multicolumn{3}{c}{ Quality } \\
\cline { 2 - 4 } & Class C & Class B & Class A \\
\hline $\begin{array}{l}\text { Front housing } \\
\text { module } \\
\text { speakers and } \\
\text { controls }\end{array}$ & $\begin{array}{l}\text { Defective } \\
\text { speakers or }\end{array}$ & $\begin{array}{l}\text { Scratched } \\
\text { Housing }\end{array}$ & $\begin{array}{l}\text { Unscratched } \\
\text { Housing }\end{array}$ \\
\cline { 2 - 4 } & Broken & Scratched & Unscratched \\
& housing & Housing & Housing \\
\hline Back housing & Broken & Scratched & Unscratched \\
\hline
\end{tabular}

\subsubsection{Audio testing}

Speaker and sound card functionality are determined in what is denoted by acoustic testing. A faulty reproduction of a standardized sound signal usually originates from either speaker or sound cards defects and requires testing components. Electric and acoustic testing requires a simple PC, only.

\subsubsection{Display testing}

The electronic testing of the LCD-Module requires a device to generate standardized test signals and to analyse electric measurements. Damaged gate or data driver chips, as well as damaged TFT can be the cause of defective pixel or sub-pixel. The standard ISO 13406-2 defines the quality criteria for pixel error tolerance. Limits for constantly bright or dark as well as defective sub pixels are defined. The standard ISO 13406-2 provides customers and manufacturers with a clearly defined and thus comparable warranty claim definition, in which the pixel fault classes are given. As an example for a 15" LCD panel, a maximum of 4 defective sub pixels or 2 defective bright or black pixels are accepted for category II, i.e., quality class A. Up to 500 defective sub pixels or 50 bright respectively, 150 dark pixels are considered as quality class B. 
Test patterns generated by a personal computer (PC) or a "stand-alone-unit" as given in Figure 16 can be used to identify these defects manually by means of a visual test. Moreover, the "stand-alone-unit" can be used for electronic testing of the inverter board and digital interface of a disassembled LCD-Module.

Other defects caused by usage include scratched polarizers, defective row or column controllers, defective TABs or drivers or aged color filters. Table 2 summarizes the defined quality classes for LCD modules.

\subsubsection{Logical testing}

Logic testing comprised the options of monitor adjustments using the monitor's panel and on-screen-display (OSD) as well adjustments carried out using the PC setup software. Examples are clock phase, contrast, and auto adjust (OSD) or frequency and resolution (software).

\subsection{Electronic fault diagnosis of LCD monitor components}

The simple testing of the product's functionality is usually considered reasonable, as long as no security relevant functions are jeopardized. Functionality by itself does not ensure the faultlessness of the electronic component. An assignment of errors for components when failures are identified can hardly be achieved. Disassembly for

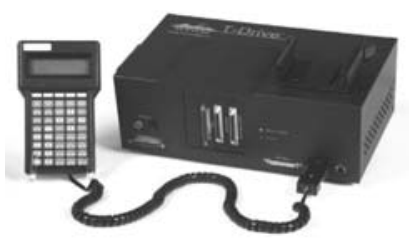

- Backlight

(on/off and light/dark)

- Voltage and Amperage

- Resolutions

- Automatical Test Pattern

(Single colors, lines of columns)

Figure 16. "T-Drive" for LCD module testing.

Table 2. Standard components of the LCD monitor.

\begin{tabular}{|c|c|c|c|}
\hline \multirow[t]{2}{*}{ Component } & \multicolumn{3}{|c|}{ Quality } \\
\hline & Class C & Class B & Class A \\
\hline \multirow{5}{*}{$\begin{array}{l}\text { Liquid } \\
\text { Crystal } \\
\text { Display } \\
\text { Module }\end{array}$} & Glass substrate & \multirow{3}{*}{$\begin{array}{l}\text { Pixel defect } \\
\text { category III } \\
\text { or IV (ISO } \\
13406-2)\end{array}$} & \multirow{4}{*}{$\begin{array}{l}\text { Pixel defect } \\
\text { category I or } \\
\text { II (ISO } \\
13406-2)\end{array}$} \\
\hline & Bevond category & & \\
\hline & IV (ISO 13406-2) & & \\
\hline & $\begin{array}{l}\text { Defective row or } \\
\text { column controller }\end{array}$ & $\begin{array}{l}\text { Scratched } \\
\text { polarizer }\end{array}$ & \\
\hline & $\begin{array}{l}\text { Defective contacts, } \\
\text { tape adhesive } \\
\text { bonding (TAB) or } \\
\text { data or gate driver }\end{array}$ & $\begin{array}{l}\text { Aged color } \\
\text { filter }\end{array}$ & \\
\hline $\begin{array}{l}\text { Cold Cathode } \\
\text { Fluorescent } \\
\text { Lamp } \\
\text { (CCFL) }\end{array}$ & Broken & $\begin{array}{l}\text { Weak } \\
\text { emission }\end{array}$ & Bright \\
\hline
\end{tabular}

component level enables extended testing and therefore the containment of failures. Intensive diagnoses under different environmental conditions using predetermined procedures are required when components are not only to be reused, but to be remanufactured to new products.

Different test methods for electronic components are applied in production processes. Table 3 shows applied methods comparing the contrasts. The test methods were analyzed and their applicability for remanufacturing evaluated.

Signature analysis was identified as a suitable diagnostic method, a diagnostic tool to examine critical performance parameters of subassemblies and components. Signatures of used parts are compared to those of new parts, respectively "good"-parts are compared to "bad"parts. Signatures of standard electronic components are given in Figure 17.

Signature analysis was applied to basic electronic component. Figure 17 depicts the respective signatures for each basic component using a simple test setup including oscilloscope, frequency synthesizer, modifiable resistor and wires. Figure 18 presents the circuit diagram.

After validating the applicability of signature analysis for LCD monitor's component testing with the simple test setup, professional signature analysis equipment including PC interface and software from Huntron (http://www. huntron.com, 2006) was applied. Figure 19 illustrates the test setup and an exemplarily application of signature analysis for a converter board.

Figure 20 depicts the deviation of signatures between a functional and a faulty converter board as tested and analyzed by means of the applied PC Software from Huntron.

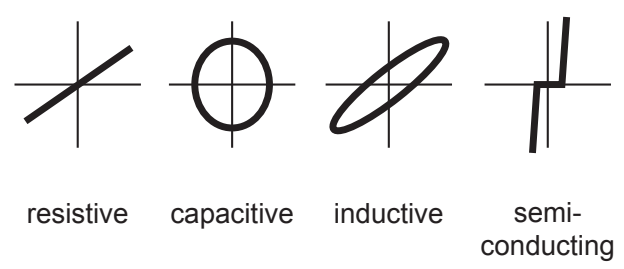

Figure 17. Standard Signatures.

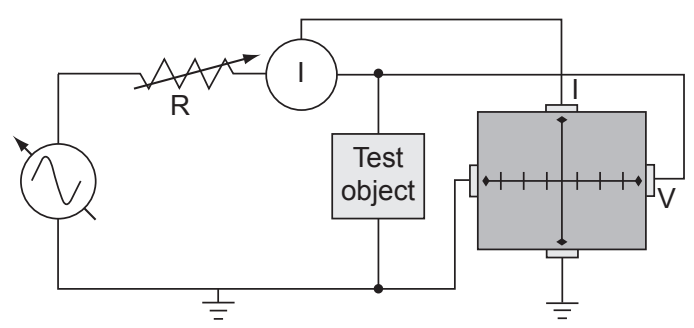

Figure 18. Circuit Diagram Signature Analysis. 
Table 3. Evaluation of testing methods.

\begin{tabular}{|c|c|c|c|}
\hline & Test method & Advantages & Disadvantages \\
\hline \multirow[t]{4}{*}{ Electrical Test } & Functional Test & $\begin{array}{l}\text { - Test of functionality of components and the whole } \\
\text { PCB; } \\
\text { - Test of programmed functionality; } \\
\text { - Identification of dynamic and thermal failures. }\end{array}$ & $\begin{array}{l}\text { - Requires Basic functionality; } \\
\text { - No identification of missing condensers; } \\
\text { - Test under power } \rightarrow \text { risk of consecu- } \\
\text { tive fault; } \\
\text { - Requires often complex test beds; } \\
\text { - Identification of failure effect; not fail- } \\
\text { ure cause }\end{array}$ \\
\hline & In-Circuit-Test & $\begin{array}{l}\text { - Test of components according to correct data; po- } \\
\text { larity; internal functionality; programmed func- } \\
\text { tionality etc.; } \\
\text { - Results simple to interpret; } \\
\text { - Power-off testing; } \\
\text { - Simple programming on component level; } \\
\text { - High automation pot ential. }\end{array}$ & $\begin{array}{l}\text { - No test of PCB functionality; } \\
\text { - Complex programming for bigger } \\
\text { PCBs; } \\
\text { - No identification of dynamic or ther- } \\
\text { mal failures; } \\
\text { - Requires digital test patterns for IC's; } \\
\text { - Complex contacting (needle bed); re- } \\
\text { quires new needle beds after layout } \\
\text { changes; } \\
\text { - Inflexible for repair services. }\end{array}$ \\
\hline & $\begin{array}{l}\text { Boundary-Scan- } \\
\text { Test }\end{array}$ & $\begin{array}{l}\text { - Simple Contacting; } \\
\text { - Test of complex components (IC's); } \\
\text { - Power-off testing. }\end{array}$ & $\begin{array}{l}\text { - No test of PCB functionality; } \\
\text { - Complex programming; } \\
\text { - No identification of dynamic or ther- } \\
\text { mal failures. }\end{array}$ \\
\hline & $\begin{array}{l}\text { Signature } \\
\text { Analysis }\end{array}$ & $\begin{array}{l}\text { - Identification of typical production failures and de- } \\
\text { fect components; } \\
\text { - No component library necessary; } \\
\text { - Technology independent; } \\
\text { - Power-off testing; } \\
\text { - Simple Programming („Good“-Signature). }\end{array}$ & $\begin{array}{l}\text { - Restricted recognition of failures in } \\
\text { component networks; } \\
\text { - No measurement of component data } \\
\text { and tolerances; } \\
\text { - No identification of dynamic or ther- } \\
\text { mal failures; } \\
\text { - Requires interpretation of operator. }\end{array}$ \\
\hline \multirow[t]{2}{*}{ Optical Tests } & $\begin{array}{l}\text { Automatical- } \\
\text { Optical Inspec- } \\
\text { tion }\end{array}$ & $\begin{array}{l}\text { - High automation potential; } \\
\text { - Character recognition } \rightarrow \text { recognition of compo- } \\
\text { nents etc. }\end{array}$ & $\begin{array}{l}\text { - Complex programming; } \\
\text { - No test of PCB functionality; } \\
\text { - No identification of shorts below com- } \\
\text { ponents respectively inside the PCB. }\end{array}$ \\
\hline & $\begin{array}{l}\text { Automatical-X- } \\
\text { Ray Inspection }\end{array}$ & $\begin{array}{l}\text { - Identification of shorts below components respec- } \\
\text { tively inside the PCB. }\end{array}$ & $\begin{array}{l}\text { - Complex programming; } \\
\text { - No test of PCB functionality; } \\
\text { - No recognition of wrong component } \\
\text { data; } \\
\text { - Automatically picture evaluation often } \\
\text { not possible; } \\
\text { - Requires interpretation of operator. }\end{array}$ \\
\hline
\end{tabular}

In the following, approaches to increase the efficiency of remanufacturing by improving the product design are introduced.

\section{Design improvements for efficient remanufacturing}

Today's industry is confronted with challenges to increase the profitability of remanufacturing. Most of these challenges are caused by mainly high complexity of products, many product variants as well as technological and stylistic obsolescence. These challenges are contributing to less profitability of remanufacturing processes, especially for mass products, e.g. flat screen monitors and mobile tele-phones.

Two parallel paths have been developed in order to cope with the described challenges. The paths are exem- 


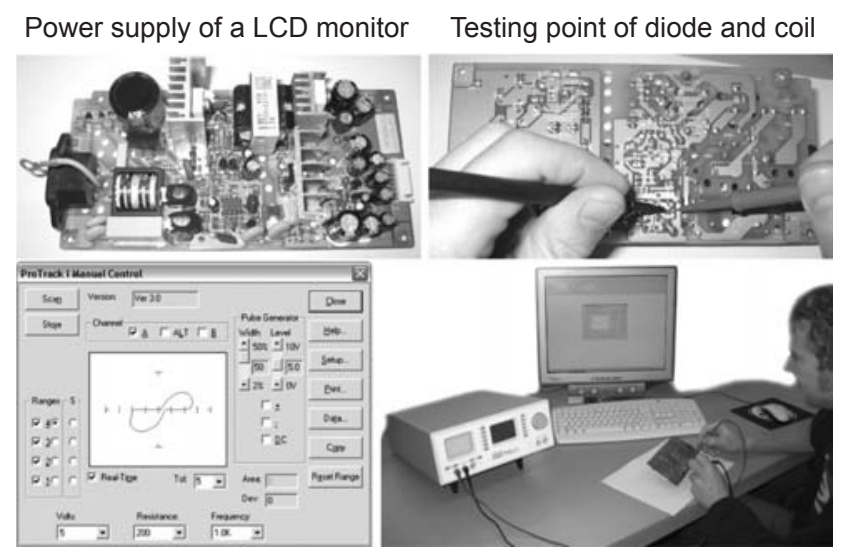

Signature of a semiconducting and an inductive component (diode and coil)

Figure 19. Application of signature analysis.

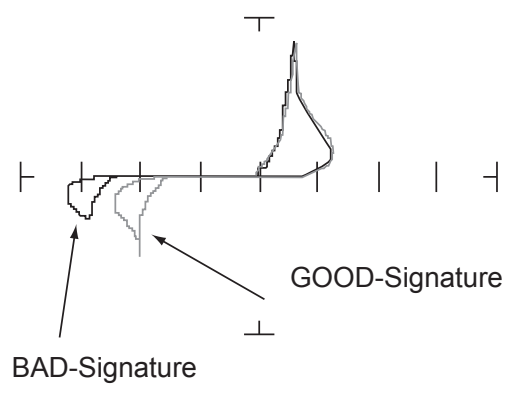

Figure 20. Deviation due to short circuit.

plarily illustrated in the example of mobile tele-phones. The first path, the reactive path was to develop a single flexible mobile tele-phone housing concept that would permit the inclusion of electronic components from a wide range of existing products. This concept was called the Mobile Tele-phone Housing Platform (MTHP). The feasibility of the MTHP concept has been demonstrated by a physical prototype, which was capable to incorporate electronic components from at least three different mobile tele-phone models from the same Original Equipment Manufacturer (OEM) (Seliger et al., 2003). Advantageous of the concept is that it can be pursued by the remanufacturer themselves in order to decrease the cost for spare part acquisition respectively the acquisition of cosmetic parts, which are the important cost drivers by remanufacturing of mobile tele-phones.

\subsection{Mobile tele-phone housing platform (MTHP)}

The MTHP, which is able to fit electronic components from different cellular tele-phone models into single housing, enables the reduction of costs in remanufacturing created by the need to purchase spare parts from
Original Equipment Manufacturers (OEMs). The MTHP approach also reduces the number of spare parts to be kept in an inventory.

The development of the MTHP concept has been developed for specific sub-classes of mobile tele-phones, since the actual number of mobile tele-phone variants available on the market was estimated to be several thousands considering only geometrical features. These variants have been categorized in the following classes: candy-bar, flip and slide phones. To define the scope of the project, mobile tele-phones available on the market were sorted according to their market share so that the MTHP could be targeted to mobile tele-phones with the highest second-hand market value.

Overall, three different MTHP designs were carried out. The first generation MTHP was developed primarily to address the large variation in length of mobile tele-phones. All components except the speaker and the microphone are fixed in the back housing using a flexible foam material with useful heat transfer characteristics. The MTHP was developed without screw connections, using instead assembly and disassembly friendly snap-, clip- and pressfit connections. After prototyping the MTHPs, it was clear that its advantage was its high flexibility in length and easy assembly and disassembly. However it was also evident that its weak point was the difficulty in aligning interior components and in its fragile structure.

To improve on the weak points of the first MTHP design, an enhanced second design was developed. The goal of high flexibility in length from the first generation was abandoned in order to enhance the structural integrity of the MTHP. In this design, the speaker, microphone, and circuit board, as well as the lens and the keypad, are fixed in the front housing, while the remaining components are fixed in the back housing using high flexibility press-fit and snapfit fasteners. The "one-size-fits-all" keypad was designed to work with each of the selected mobile tele-phones. It was presumed that alternative keypads could be offered for different cell phones. After prototyping this MTHP, it was found that structural strength, keypad flexibility, and assembly/disassembly-friendliness were its primary advantages. Its disadvantage was the inability to adjust length and its large number of parts (Seliger et al., 2003).

To achieve a more adaptable design with fewer parts, a third generation MTHP was conceived (Figure 21). The main characteristic of this MTHP is its frame tray, where all components are fixed in the proper orientation and location. Therefore the design of the housing components is completely independent from the layout of the electronic components. In this MHP, the circuit board is fixed with screws to increase its robustness to shock and vibration. The keypad is based on the same design as the second generation MTHP. The advantages of this 

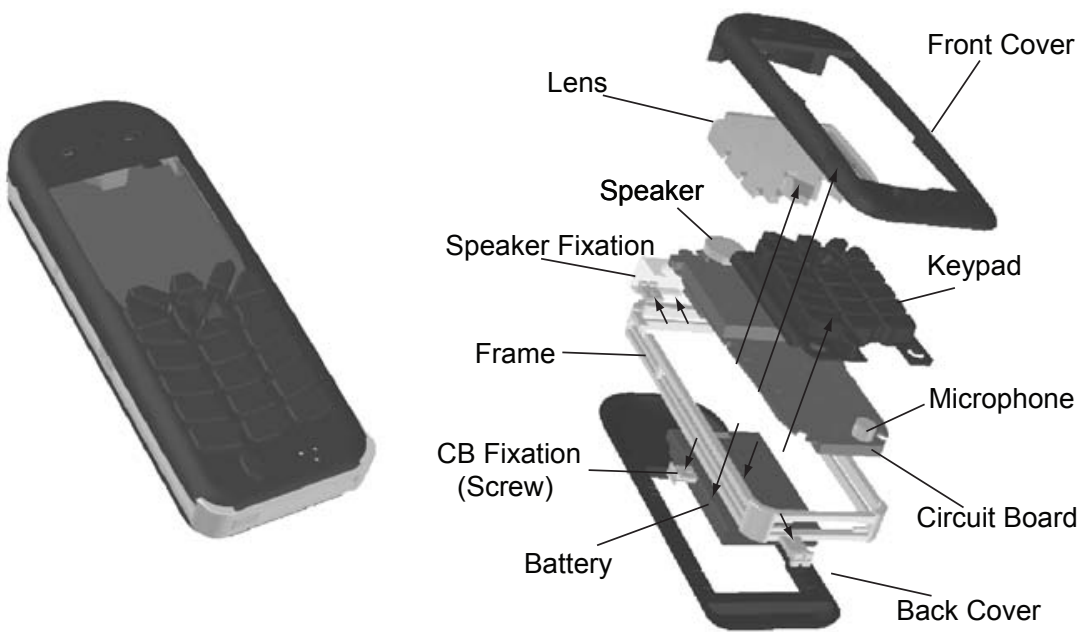

Figure 21. Third generation of Modular Tele-phone Housing Platform (MTHP) (Skerlos et al., 2004).

MTHP are its robust and flexible design, adaptability to customer needs, and "one-size-fits-all" keypad solution. Its only weakness is its limited adaptability to phones of variable length. Therefore the MTHP size was classified to different geometry (Skerlos et al., 2004).

However, the challenges which appeared when developing the MTHP led to the second path, the proactive path. The second path was to improve the product design of a mobile tele-phone in order to increase its suitability for remanufacturing, which is also called Design for Remanufacturing (DfR). In applying DfR, the challenges of remanufacturing are already considered in the product development process. Modularity hereby, is one of the key elements to achieve this goal (Figure 22). The result of pursuing the second path is the Modular Mobile Telephone (MMT). However, this concept can only be carried out by the OEM.

\subsection{Modularity: enabler for efficient remanufacturing}

Based on Göpfert, modularization can be defined as the grouping of functional carriers to physical and functional independent units or so called modules. This means that a module can fulfill at least one function independently without any additional component, e.g. power unit of a personal computer. Thereby the inner connections of modules are stronger than between modules. A vital element of physical independence is the design of disassembly and reassembly suitable module interfaces. Hereby, functions for material, signal and energy flow should be integrated in the physical design of the module interface. Module interfaces can be divided into definite, multiple and universal. The highest degree of independence is achieved by multiple and universal interfaces that allow an arbitrary exchange of the modules leading to a highly flexible product structure (Göpfert, 1998).

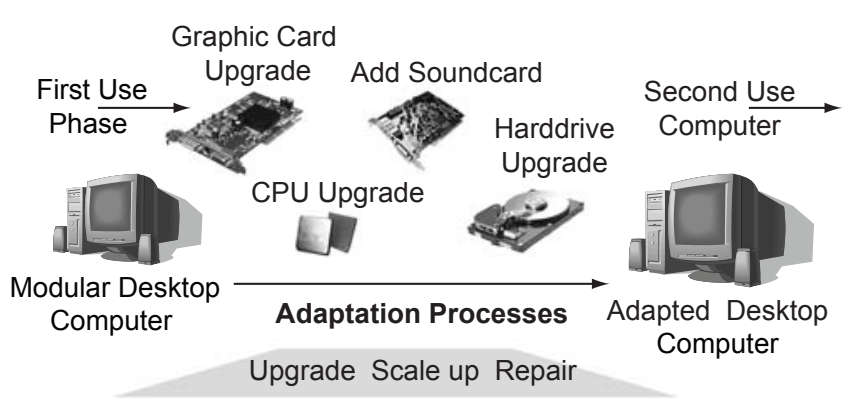

Figure 22. Remanufacturing and adaptation of modular products.

The standardization of modules and module interfaces is significant for the reuse of modules in different product generations and variations. In order to achieve functional independency of a product, the carriers of functions have to be grouped appropriately. The groupings have to be carried out with respect to different competing goals along the product life cycle, which can be described as module drivers (Erixon, 1998).

\subsection{Modular mobile tele-phone (MMT)}

The pursued goal with the development of the MMT is to reduce costs throughout the product life cycle by means of standardization, modularization and platform development. Mass customization (MC) and postponement are further aspects driving the development of the MMT.

The MMT is characterized by standardized electronic modules and housing components, as well as form-specific modules allowing for quick assembly, disassembly and reassembly of the form-factor models: candy-bar, slide and flip phone. The main reasons for modularization are defined by means of so-called module drivers (Erixon, 1998). 
The applied module drivers are:

- Product realization: Multiple use of existing technologies/components/modules for different product variants; parallel development of modules,

- Product development: Production and assembly (simple and standardized production processes and equipment), quality (separate tests of modules),

- Distribution: MC and postponement,

- Product Use: Service; and

- End of life: Disassembly and reassembly (simple and standardized production processes and equipment), adaptation (upgrade, etc.).

Modularization of the mobile phone components enables simple and fast assembly, disassembly and reassembly processes that allow for an easy module replacement, enlargement or reduction, as well as housing and formfactor change. Short development processes by parallel module development are followed by a long life cycle of the respective module, for instance by reuse. Furthermore, it is possible to adjust the mobile phone to technical innovations and individual customers' needs. Thus, customers have the possibility of determining the configuration of their mobile phones by themselves and to select between different form factors. The final assembly of the mobile phone modules and housing components can be carried out at the store by the staff or from the customer themselves (Seliger et al., 2006).
The MMT consists of one platform and five housing components, as well as eleven modules (two optional modules, five modules in different variants, three formfactor specific modules and one standard module). These modules can be arranged in the three form-factors: candy-bar, flip and slide.

Beside the modules that are used for the candy-bar tele-phone, the modules Flip mechanism and 2nd Display are added for assembling the flip tele-phone. For the slide arrangement, a nearly invisible slide mechanism (instead of the flip mechanism) and a housing cover have to be subjoined. The mobile phone can be opened by sliding the top parts over the lower parts to uncover the numerical keypad (Figure 23).

\section{Summary and Outlook}

Unequal distribution of wealth is still a major challenge in the global community. The increase of standards of living for everyone could lead to a resource consumption that will exceed ecological limits. The increase of resource productivity can contribute to a shift from cradle-to-grave to cradle-to-cradle economy and therefore to sustainable resource consumption and consequently an increased standard of living and balanced distribution of wealth. Legislation can contribute to form paths for activities in sustainability. However, legislation should only set minimal social, labour and environmental standards without hindering entrepreneurial initiative and techno-

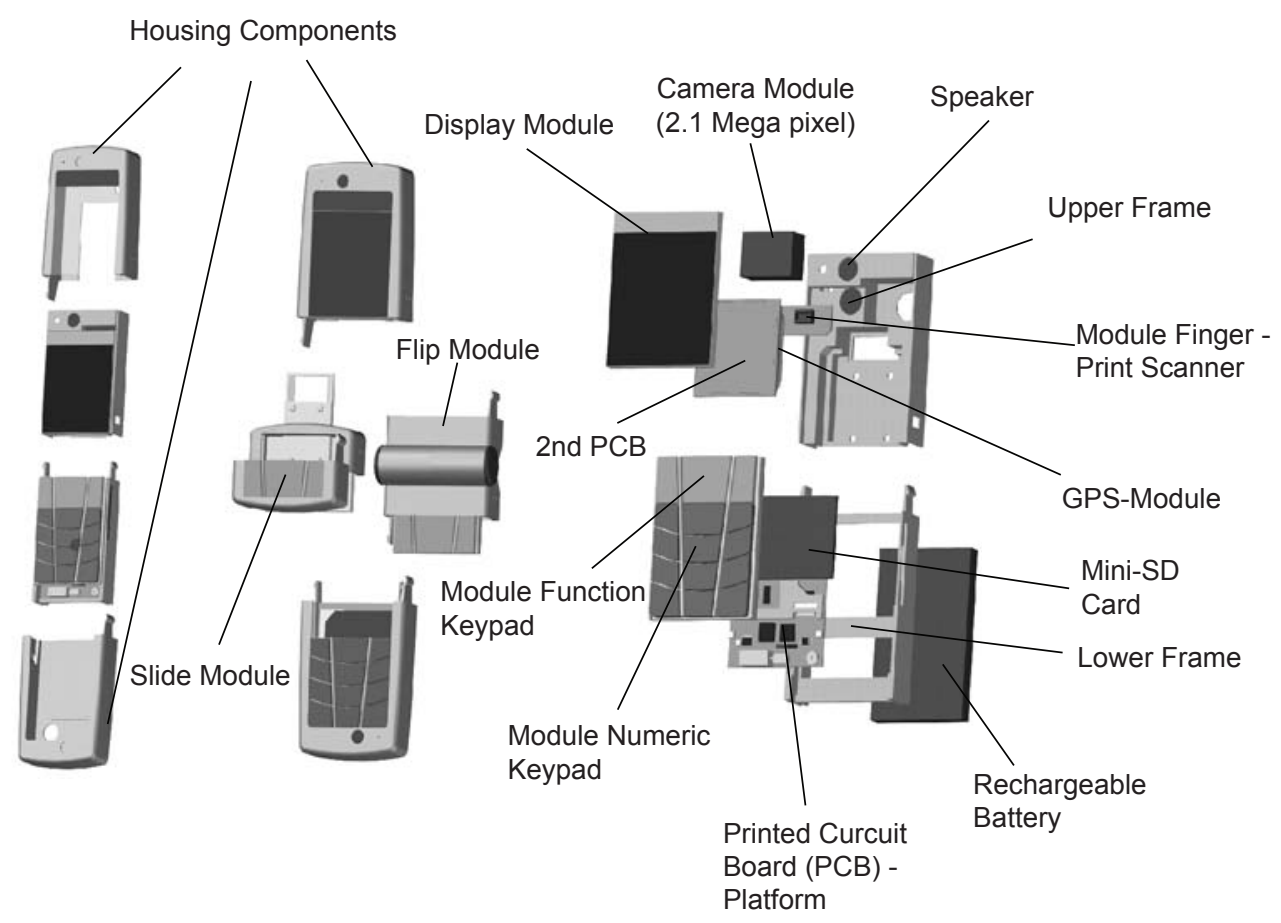

Figure 23. Virtual Prototype of Modular Cellular Tele-phone Concept (MMT) (Seliger et al., 2006). 
logical innovation in a competitive environment. European legislation on WEEE can be improved with respect to these requirements. As an example, illegal export, which is common practice to dispose of electrical and electronic waste, should be detained. Therefore, technical enablers are required to keep treatment and in particular remanufacturing activities at the origin of product return. Disassembly and testing are the main drivers for environmental conscious remanufacturing. In the example of a Modular
Mobile Tele-phone Concept (MMT), it has been shown that modularity of products supports these activities.

\section{Acknowledgments}

We express our sincere thanks to the Deutsche Forschungsgemeinschaft (DFG) for financing this research within the Collaborative Research Centre 281 on Disassembly Factories for the Recovery of Resources in Product and Material Cycles.

\section{Bibliographical References}

ALEXANDER, R. Worldwide Monitor Market Tracker. iSupply, Stanford Resources. 3. quarter 2004.

BEHRENDT, S.; ERDMANN, L. Display-Märkte im Umbruch - Neuorientierungen für Umweltschutzstrategien. Roadmap des IZT. Berlin 2003.

BASDERE, B. Beitrag zur Steigerung der Nutzenproduktivität von Ressourcen durch Anpassen von Mobiltelefonen. Reihe Berichte aus dem Produktionstechnischen Zentrum Berlin, Berlin 2004.

DISPLAYSEARCH DELIVERS BREAKTHROUGH REPORT ON LCD MONITOR MARKET, 1999. Available at www.displaysearch.com/press/1999/120999.htm

ERIXON, G. Modular Function Deployment - A Method for Product Modularization. Doctoral dissertation, Royal University of Technology, Stockholm, Sweden, 1998.

FRANKE, C.; KERNBAUM, S. Virtueller Inbetriebnahme eines Aufarbeitungssystems für Flachbildschirme. In: FUTUR 1/2005 - Mitteilungen aus dem Produktionstechnischen Zentrum Berlin, Berlin, April 2005

FRANKE, C.; SELIGER, G.; YAKUT, E. Mobile Phone Remanufacturing Program planning in Networks. In: Proceedings of the Global Conference on Sustainable Product Development and Life Cycle Engineering, uniedition, Berlin, 2004, p. 187-190

FRANKE, C.; KERNBAUM, S.; SELIGER, G.: Remanufacturing of Flat Screen Monitors - Economical and Technological Challenges until 2010 In: Proceedings of the 38th CIRP International Seminar on Manufacturing Systems (ISMS), Florianopolis, Brazil, May 2005

FRANKE, C.; KERNBAUM, S.; SELIGER, G. Remanufacturing of Flat Screen Monitors. In: Innovation in Life Cycle Engineering and Sustainable Development, Hrsg.: Brissaud, D., Tichkiewitch, S., Zwolinski, P., Springer, 2006, S. 139-152.

GERMAN BUNDESRAT: Gesetz über das Inverkehrbringen, die Rücknahme und die umweltverträgliche
Entsorgung von Elektro- und Elektronikgeräten (Elektround Elektronikgerätegesetz - ElektroG). March 2005

GERMAN BUNDESRAT: Gesetz zur Förderung der Kreislaufwirtschaft und Sicherung der umweltverträglichen Beseitigung von Abfällen. September 1994.

GÖPFERT, J. Modulare Produktentwicklung - Zur gemeinsamen Gestaltung von Technik und Organisation; Gabler Verlag/Deutscher Universitätsverlag; Wiesbaden, 1998

KÄMPKE, T.; PESTEL, R.; RADERMACHER, F. J. European Journal of Law and Economics, v. 15, iss. 2, p. 129-163(35), Kluwer Academic Publishers, March, 2003.

MARTIN, R.; BECKER, W.; SIMON-HETTICH, B. Verwertungsverfahren für LC-Displays. In: Workshop Nachhaltigkeit als Chance und Herausforderung für Unternehmen im Flachdisplaymarkt. Berlin, May 122004.

MASLOW, ABRAHAM H.: Motivation und Persönlichkeit. Reinbek, 1999.

NSC - National Safety Council. Electronic Product Recovery and Recycling Baseline Report: Recycling of Selected Electronic Products in the United States. Washington DC. May 1999.

PERCHARDS: Transposition of WEEE \& RoHS Directives into national law of EU Member States* and corresponding industry activities - Summary of Perchards' Quarterly End-of-Life Policy Updates. April, 2005.

SCHMIDT-BLEEK, F. Wieviel Umwelt braucht der Mensch? MIPS - Das Maß für ökologisches Wirtschaften, Birkhaeuser, 1993, English translation: The Fossil Makers - Factor 10 and More, available at www.Factor10 Institute.org

SELIGER, G., SKERLOS, S. J.; BASDERE, B.; ZETTL, M. Design of a Modular Housing Platform for Remanufacturing of Multiple Cellular Phone Models, Eco-Design 2003, Tokio, 2003. 
SELIGER, G. Global Sustainability - A Future Scenario. In: Proceedings of the Global Conference on Sustainable Product Development and Life Cycle Engineering, Publisher uni-edition, Berlin 2004, p. 29-35

SELIGER, G.; KERNBAUM, S.; ZETTL, M. Approaches for Sustainable Manufacturing. In: 7th. International Conference on. Frontiers of Design and Manufacturing, Guangzhou, p. 19-22, China, June 2006.

SELIGER, G.; BASDERE, B.; CIUPEK, M.; FRANKE, C. Contribution to Efficient Cellular Phone Remanufacturing. In: CIRP Seminar on Life Cycle Engineering, Copenhagen. Denmark, May 2003.

SKERLOS, S. J.; ZETTL, M.; BASDERE, B.; SELIGER, G. Collaborative Development of Sustainable Strategies for the Reuse of Mobile Phones in a Global Educational Environment. In: Proceedings Global Conference on Sustainable Product Development and Life Cycle Engineering, Berlin, Germany, 29.09 - 01.10.2004, S. 337-344.

RADERMACHER, F. J. Balance oder Zerstörung. Ökosoziale Marktwirtschaft als Schlüssel zu einer weltweiten nachhaltigen Entwicklung. Österreichischer Agrarverlag Druck- und Verlagsges.m.b.H., 2002

THE EUROPEAN PARLIAMENT, THE COUNCIL: Directive of the European Parliament and of the Council on Waste from Electrical and Electronic Equipment (WEEE). Brussels, 2002

UMWELTBUNDESAMT: Ecotoxicology of Liquid Crystals in Liquid Crystal Displays. . 2000.

UNIVERSITY OF TENNESSEE 2001, University of Tennessee, US-Environmental Protection Agency, Desktop Computer Displays - A Life Cycle Assessment, 2003. Available at www.epa.gov.

WILLIAMS, E. D.; AYRES, U. A.; HELLER, M. "The 1,7 Kilogram Microchip: Energy and Material Use in the Production of Semiconductor Devices", Journal of Environmental Science and Technology, v. 36, n. 24, p. 5504-5510, 2002.

ZDF: FRONTAL 21. 17. January 2006, http://www.huntron. com/. Last access: 31.01 .2006

\section{ABORDAGENS DE REMANUFATURA - UMA CONTRIBUIÇÃO PARA ENGENHARIA SUSTENTÁVEL}

\section{Resumo}

O crescente uso de recursos gerado pelo contínuo crescimento populacional inserido em um cenário de distribuição desigual de riqueza faz do termo sustentabilidade um tópico urgente para discussão. Neste artigo, apresenta-se um modelo de referência para sustentabilidade em engenharia que aborda questões relevantes para uma mudança global no caminho para a sustentabilidade, priorizando os seguintes elementos: educação e pesquisa; gestão, tecnologia, processos e produtos. As leis ambientais da União Européia esforçam-se para tratar com responsabilidade esse desafio de desenvolvimento sustentável. A realidade de implementações práticas em consideração a produtos eletro-eletrônicos depois de sua fase de uso é ilustrada no artigo. Desenvolvimentos em laboratório de desmontagens e testes demonstram a viabilidade da remanufatura. Além disso, abordagens para aumentar a eficiência do processo de remanufatura a partir de melhorias no processo de desenvolvimento do produto são também sugeridas.

Palavras-chave: sustentabilidade, engenharia, remanufatura, projeto para manufatura, modularidade. 